\title{
US legislator warns of hollow promises on research spending
}

[WASHINGTON] US scientists are fooling themselves if they expect the Congress to honour recent pledges to double research spending over the next decade, according to one of the country's most experienced science legislators.

An analysis conducted for the office of George Brown (Democrat, California) by the Congressional Research Service says that the budget resolution passed by the Senate on 2 April would actually result in a small decline in spending on civilian research and development over the next five years.

Spending in agencies other than the National Institutes of Health (NIH) would drop by 17 per cent, from $\$ 22$ billion to $\$ 18.5$ billion by the year 2003 .

$\mathrm{NIH}$ would receive an 11 per cent increase in funding next year, to $\$ 15.1$ billion, under the budget resolution, an important guide to the budget for the 1999 fiscal year which Congress must agree on by 1 October.

Brown is the senior Democrat on the Science Committee in the House of Representatives. His committee oversees research at the National Science Foundation (NSF), the National Aeronautics and Space Administration and the Department of Energy, and his attack on the resolution reflects his concern that funding prospects are darkening for science agencies other than NIH.

Brown argues that it is the budget resolution, rather than a separate bill proposed in the Senate that would double research spending over ten years, that shows the real intentions towards science of senior Republican senators.

Two sponsors of the bill, known as S1305 - Senators Phil Gramm (Republican, Texas) and Pete Domenici (Republican, New Mexico) - sit on the budget committee, which drew up the resolution. Brown says: "Even with key champions of S1305 in the room, when it came to making hard choices, the cheap talk stopped and dollars went to other purposes."

Larry Neill, a spokesman for Gramm, responds to the charge by accusing Brown of "indulging in cheap partisanship" which could endanger the S1305 proposal. Neill says that Gramm hoped to pass the bill this year, with a view to influencing budget resolutions in future years. But there is no companion measure in the House of Representatives, and it is not considered likely to pass into law.

Gramm did successfully propose a 'sense of the Senate' amendment to the budget resolution, stating that the Senate intends civilian research and development spending to be doubled over ten years. But the Senate passed several such amendments to its budget resolution, and critics point out that they allow the legislative body to commit words without spending any money.

Prospects for research increases in the budget for 1999 remain uncertain. Despite doubts about the achievement of a tobacco settlement that would finance such increases in the budget submitted to the Congress by President Bill Clinton in February (see Nature 391, 521-522; 1998), most science lobbyists are optimistic that money will be found to pay for the proposed increases.

The appropriations subcommittees that work on the budget have begun their annual process of reviewing the science agencies, although they do not yet know how much

money they will have to fund the programmes they oversee. The House has not yet drawn up a budget resolution to match the Senate's, and is not expected to do so until next month.

According to science lobbyists, the appropriations subcommittees are likely to receive initial funding allocations in late spring that will be insufficient to meet their members' aspirations. Attempts will then be made to find extra money - from a tobacco settlement or some other source.

A last-minute scramble is then likely to take place in September to ensure that key programmes are funded before congressmen return triumphantly to their districts to seek approval in November's elections from the people whose money they have spent.

ColinMacilwain

\section{Europe may pool marine research efforts}

[PARIS] Three marine research agencies in Europe are planning to take further steps towards the creation of a unified European fleet of research vessels with a common scientific programme. The initiative represents a major step towards integrating the agencies' operations, and coincides with separate preliminary plans to float a

European Maritime Agency (see Nature 392, 323 ; 1998).

The lead in the project is being taken by the Triangular Liaison Group (G3), which was set up by the principal bodies responsible for marine research in the United Kingdom, France and Germany in 1996 to strengthen cooperation on large marine facilities. The group has already agreed with the ship operators of each agency on pooling the use of their research vessels (see Nature 379, 576; 1996).

G3 brings together Britain's Natural Environment Research Council (NERC), the French Institute for Research into the Exploitation of the Sea (IFREMER), and Germany's ministry of research, education and technology (BMBF).

Concrete steps towards closer integration are expected to emerge from the the group's next meeting in June. This will bring together not only the research ship operators, but also representatives of the peer review committees that approve research strategy within each agency.

According to Pierre Nounou, the official responsible for the G3 at IFREMER, the initial goal is to agree on common research programmes, with the ultimate aim of having a single evaluation committee for

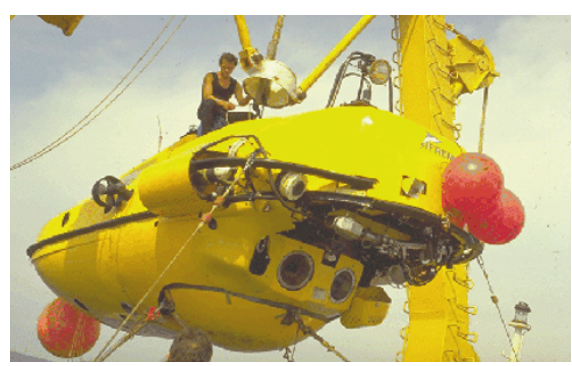

Navigating towards unification: vessels such as Cyana may come together for European research.

research proposals and a single group of ship operators. "This would amount to a European fleet of research vessels," he says, adding that the construction of new joint European vessels is also on the agenda.

The current agreement is limited to Germany, France and the United Kingdom, which together represent more than 80 per cent of Europe's marine science resources. These countries are also the world's foremost marine science powers with a combined marine research workforce of more than 7,000 and a budget of FFr4.3 billion (US\$700 million) - roughly equivalent to that of the United States, Canada and Japan combined.

Under longer-term plans, the tripartite agreement would be opened to the smaller European countries. These have a joint research workforce of 1,420 and a budget of FFr930 million, but often lack ships, submarines and other large facilities. Researchers from these countries could be included in research projects, for example, in return for a subscription. Declan Butler 